\title{
Chemical Characteristics and Source Apportionment of Polycyclic Aromatic Hydrocarbons (PAHs) in Surface Sediments of the Ikizcetepeler Dam Lake of Northwestern Turkey
}

\author{
Tansel Topal ${ }^{1}$, Lokman H. Tecer ${ }^{1}$ and Semra G. Tuncel ${ }^{2}$ \\ ${ }^{1}$ Namik Kemal University, Department of Environmental Engineering, 59860, Corlu, Tekirdag, Turkey \\ ${ }^{2}$ Middle East Technical University, Chemistry Department, 06531, Ankara, Turkey \\ "Corresponding author: Semra G. Tuncel, Middle East Technical University, Chemistry Department, 06531, Ankara, Turkey, Tel: +903122103195; Fax: \\ +903122103200; E-mail: semratun@metu.edu.tr
}

Rec date: July 16, 2014, Acc date: September 09, 2014, Pub date: September 11, 2014

Copyright: (C) Topal T, et al. This is an open-access article distributed under the terms of the Creative Commons Attribution License, which permits unrestricted use, distribution, and reproduction in any medium, provided the original author and source are credited.

\begin{abstract}
The concentrations of 16 polycyclic aromatic hydrocarbons (PAHs) in surface sediments collected from 44 sites of the İkizcetepeler Dam Lake, in Balıkesir province of Northwestern Turkey are determined. The soxhlet extraction procedures had been optimised and validated by using gas chromatography-Mass detector (GC_Mass). Recovery was in between $56-124 \%$. Relative standard deviation was less than $1 \%$ and limit of detection changed from 0.0010 to $0.028 \mathrm{\mu g} / \mathrm{g}$. The accuracy of the method was verified by analyzing National Institute of Standards and Technology, Standard Reference Material 1597 (NIST SRM 1597). The selectivity, accuracy and precision were quite adequate for the determination of PAHs in sediment samples. The sum PAH concentrations was $0.19 \pm 0.07$ $\mathrm{mg} / \mathrm{kg}$. The Factor Analysis (FA) and diagnostic analysis results indicated that pyrogenic and petrogenic sources are the important sources of PAHs. Further analysis showed that contributions of Factor 1 (mixed) and Factor 2 (pyrogenic) are $37.9 \%$ and $26.9 \%$ respectively. Factor 3 (explains 15.4 of the total variance), represents petrogenic (spills of oil products) source.
\end{abstract}

Keywords: GC-MASS; PAH; Sediment; Factor analysis; Diagnostic ratios

\section{Introduction}

Sediments in river, sea, lake and dams serves as a sink for a variety of pollutants including especially hydrophobic ones such as polycyclic aromatic hydrocarbons (PAHs). It is important to determine sediment pollution since pollutants in sediments are transferred to water body which in turn affects organisms and living species. This fact is especially critical for dams where community drinking water is supplied as public health is directly affected as well as living species in the water. Therefore, for drinking water quality determinations levels of the pollutants should be precisely determined and necessary precautions should be taken if necessary [1].

PAHs are important pollutants among the others since they are toxic, carcinogen, mutagenic and 16 of them considered as USEPA micropollutants [2]. In order to be able to control PAH concentrations, first their source need to be fully understood. PAHs in water environment are formed mainly by three processes; pyrogenic, petrogenic and biogenic. Pyrogenic PAHs are formed by incomplete combustion of organic materials like plant and fossil fuels. Pyrene like high molecular weight PAHs are accumulated in this group. Petrogenic PAHs are part of fossil fuels and they have generally lower molecular weights. Biogenic PAHs are also formed by diagenesis of biogenic material. Retene and perylene are the examples to this type [3]. By using specific PAH ratios source of the PAHs can be identified and is known as diagnostic ratio analysis. Factor analysis (FA) is another statistical method used for source apportionment. It is a data reduction tool and examines the inter-relations between the variables. Since FA should be run with more variables it provides more detailed and valid information [4]. In this study varimax rotated FA with Kaiser Criterion were used.

The aim of this study is to determine chemical concentrations and major contributing sources of PAHs in İkizcetepeler Dam Lake sediments. Analyses were performed using GC-MS after microextraction. Source determination was achieved by diagnostic ratio analysis and factor analysis. Evaluation against Sediment Quality Guidelines (SQGs) addressed ecotoxicological risks of the produced PAH data. The nineteen PAHs, including 16 PAHs identified by US EPA as priority pollutants, were monitored in surface sediments. The results of this study will provide valuable information for the environmental quality of İkizcetepeler Dam Lake.

\section{Experimental}

\section{Materials and methods}

All chemicals used during the study were of analytical reagent grade. The PAH-mix $68(100 \mathrm{mg} / \mathrm{L}$ in Cyclohexane) and internal standard-mix $25(500 \mathrm{mg} / \mathrm{L}$ of Acenaphtene-D10, Perylene-D12, Chrysene-D12, Phenantherene-D10 in Acetone) from Dr. Ehrenstorfer, were used for the analysis of PAHs. Standards for the calibration curve were prepared by diluting them with dichloromethane (DCM, Merck, HPLC-grade). Standard reference material; SRM 1597a (complex mixture of PAHs from coal tar prepared in DCM), were bought from National Institute of Standards and Technology. High purity of helium (99.999\%), glass-wool and sodium sulphate $\left(\mathrm{Na}_{2} \mathrm{SO}_{4}\right.$, anhydrous extra pure, Merck) were used for the analyses. The sodium sulphate and glass-wool were pre-cleaned by transferring them to a large glass column ( $1 \mathrm{~L}$ capacity or larger) and 
Citation: Topal T, Tecer LH, Tuncel SG (2014) Chemical Characteristics and Source Apportionment of Polycyclic Aromatic Hydrocarbons (PAHs) in Surface Sediments of the Ikizcetepeler Dam Lake of Northwestern Turkey. J Environ Anal Chem 1: 117.

Page 2 of 7

washing sequentially with acetone (Ac) and DCM before use. Sodium sulphate was activated in an oven at $400^{\circ} \mathrm{C}$ for $4 \mathrm{~h}$. Glass-wool was conditioned overnight at $225^{\circ} \mathrm{C}$ in an oven. The alconox detergent powder (Supelco Cat. No. 1104) was used for the cleaning of all glassware used in laboratory. All glass wares were cleaned with detergent in hot water and rinsed with deionized water. After being rinsed with DCM/Ac, they were dried in an oven overnight.

All the PAH analysis was performed with Hewlett-Packard (HP) 6890 GC system equipped with a 5973 mass selective detector. Heidolph rotary evaporator (laborota 4000 efficient) and mini-vap evaporator with 6 ports (Catalog No: 22970, Cat. No: 22971) were used for the evaporation of solvents. Bransonic ultrasonic bath (Model B-2200 E4, $205 \mathrm{~W}, 220 \mathrm{~V}$ ) was used for the sample extractions. Deionized water (ultra filtered type 1 water) was supplied by Barnstead nanopure ultrapure water system.

\section{Sample collection and PAH analyses}

İkizcetepeler Dam Lake (Figure 1) is situated $20 \mathrm{~km}$ south of Balıkesir province. It was constructed between the years 1986-1992 across Kille stream and is fed by Akçaköy, Taşköy and Kozludere creeks. The Dam Lake is used to irrigate Pamukçu and Aslihantepecik plains and is also used for drinking water since 2003 [5].

The İkizcetepeler Dam Lake has been spreaded over a broad land including a village (Selimiye), agricultural fields and the Balıkesirİzmir highway. Today, agricultural applications are carried out around it and the new Balıkesir-İzmir highway passes over it [6]. The location of sampling site is given on Figure 1. The surface of the İkizcetepeler Dam Lake is $9.6 \mathrm{~km}^{2}$ and the overall volume is $164,56 \mathrm{hm}^{3}$. The minimum code (water level above sea level) is $49.75 \mathrm{~m}$ and the maximum code is $175 \mathrm{~m}$. According to the measurements taken in April 2000, the maximum depth was $47.0 \mathrm{~m}$ [7].

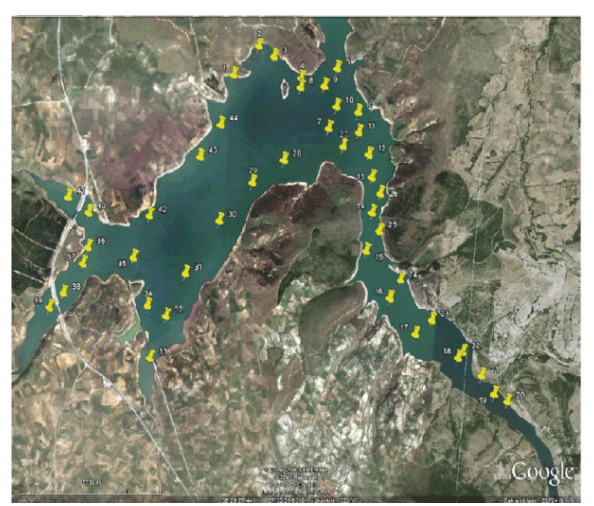

Figure 1: Sampling Points in İkizcetepeler Dam Lake

The top $0-1 \mathrm{~cm}$ surface layer was collected by using grab sediment sampler. Samples (100-250 g) were stored in a refrigerator at $-20^{\circ} \mathrm{C}$ in colored nylon bags in order to prevent any damage caused by the sunlight.

Soxhlet extraction was optimized using chemometrics and optimized conditions were used for the extraction of 44 sediment samples collected from İkizcetepeler Dam Lake. Surrogates were added to each sample before an extraction in order to observe extraction efficiency. Five gram (air dried) sediment was weighted into an extraction vessel. After spiking with surrogate standard, $1 \mathrm{ml}$ of 6.5 $\mu \mathrm{g} / \mathrm{ml} 2$-fluorobiphenyl in methylene chloride, the sample was extracted in a $50 \mathrm{ml}$ beaker for about 10 minutes with an $10 \mathrm{ml}$ of DCM and hexane mixture $(1: 1, \mathrm{v} / \mathrm{v})$. The same procedure was repeated with a mixture of hexane $(5 \mathrm{ml})$ and DCM $(5 \mathrm{ml})$ twice more for a total volume of $30 \mathrm{ml}$.

Totally four surrogates were used and each surrogate was assigned to the different set of PAHs according to number of rings. For example, Acenaphtene-D10 (Ace-D10) and Phenanthrene-D10 (PheD10) were used for the recovery calculations of 3 rings PAHs, Chrysene-D12 (Chr-D12) for 4 rings PAHs and Perylene-D12 (PerD12) for the 5-6 rings PAHs. Calculated average recoveries $(n=26)$ of surrogates in sediment samples were $41 \%, 60 \%, 85 \%$ 86\% for Ace D10, Phe D10, Chr D12 and Per D12 correspondingly. By using these recovery values concentrations of the PAHs in İkizcetepeler sediment samples were corrected as depicted in Table 1, which is showing, Certified Concentrations (mg/L) and \% Recoveries of PAHs in SRM 1597a (complex mixture of PAHs from coal tar prepared in DCM) for GC-MS $(n=4)$

\begin{tabular}{|l|l|l|l|l|}
\hline \multirow{2}{*}{ SRM 1597a } & Certified Conc. & Found Conc. & $\%$ & $\%$ \\
\cline { 2 - 5 } & $(\mathrm{mg} / \mathrm{L})$ & $(\mathrm{mg} / \mathrm{L})(\mathrm{n}=4)$ & Error & Recovery \\
\hline Nap & $896 \pm 87.0$ & $479 \pm 10.7$ & -46.6 & 53.4 \\
\hline Acy & $229 \pm 6.00$ & $184 \pm 6.85$ & -19.5 & 80.5 \\
\hline Ace & $6.63 \pm 0.230$ & $7.90 \pm 0.258$ & 19.2 & 119 \\
\hline Fle & $126 \pm 3.00$ & $104 \pm 5.65$ & -17.8 & 82.2 \\
\hline Phe & $395 \pm 6.00$ & $325 \pm 7.54$ & -17.8 & 82.2 \\
\hline Ant & $93.0 \pm 2.60$ & $76.9 \pm 2.88$ & -17.4 & 82.6 \\
\hline Fla & $284 \pm 6.00$ & $257 \pm 10.1$ & -9.67 & 90.3 \\
\hline Pyr & $209 \pm 6.00$ & $197 \pm 3.16$ & -5.74 & 94.3 \\
\hline BaA & $85.3 \pm 2.00$ & $105 \pm 41.6$ & 23.5 & 124 \\
\hline Chr & $57.6 \pm 4.60$ & $76.5 \pm 31.3$ & 32.7 & 133 \\
\hline BbF & $57.5 \pm 3.80$ & $54.8 \pm 3.35$ & -4.7 & 95.3 \\
\hline BbK & $35.8 \pm 0.400$ & $53.6 \pm 2.86$ & 49.7 & 150 \\
\hline BeP & $43.8 \pm 0.900$ & $33.1 \pm 1.75$ & -24.5 & 75.5 \\
\hline BaP & $81.3 \pm 1.20$ & $43.2 \pm 2.86$ & -46.9 & 53.1 \\
\hline BgP & $43.9 \pm 0.500$ & $33.5 \pm 3.24$ & -23.7 & 76.3 \\
\hline DaA & $6.03 \pm 0.350$ & $5.80 \pm 0.909$ & -3.81 & 96.2 \\
\hline
\end{tabular}

Table 1: Certified Concentrations (mg/L) and \% Recoveries of PAHs in SRM 1597a (complex mixture of PAHs from coal tar prepared in DCM) for GC-MS $(n=4)$

Since PAH concentrations should be given on a dry weight basis, water content of the sediments was determined and found as $56 \%$ in average $(n=10)$. By the subtraction of moisture content dry weights of the samples were calculated and these weights were used for the calculations. The procedure for the extraction of sediment samples is detailed in another article [8]. 
Citation: Topal T, Tecer LH, Tuncel SG (2014) Chemical Characteristics and Source Apportionment of Polycyclic Aromatic Hydrocarbons (PAHs) in Surface Sediments of the Ikizcetepeler Dam Lake of Northwestern Turkey. J Environ Anal Chem 1: 117.

Page 3 of 7

As instrumental analyses GC-MS was used and its features were discussed below. Before starting analysis with GC-MS, some important parameters like injection volume, inlet temperature, carrier gas $(\mathrm{He})$ flow rates, oven temperature program parameters (initial oven temperature, ramp rate and initial time) and make-up gas flow rate were optimised. Mass dectector and quadropole source temperatures were respectively. As column, HP-5 5\% Phenyl Methyl Siloxane column ( $30 \mathrm{~m}$ length and $0.32 \mathrm{~mm}$ ID $0.25 \mu \mathrm{m}$ film thickness) was chosen as best and used during PAH analysis. Helium was used both carrier and make up gas. Splitless mode was used. Injection volume was $2 \mu \mathrm{l}$ and inlet temperature was. (He) flow was $1.5 \mathrm{ml} \mathrm{min}^{-1}$ similar to the GC-MS conditions. Hydrogen and air ratios were optimized and their values were chosen as $40 \mathrm{ml} \mathrm{min}{ }^{-1}$ and $400 \mathrm{ml} \mathrm{min}^{-1}$ respectively. It was necessary to optimize these values to create more stable flame which provides better ionization and lower background.

The method detection limits (MDL) of the each target analytes for GC-MS were determined and the results were given in Table 2.

\begin{tabular}{|l|l|l|l|}
\hline No & Abbreviations & Name & GC-MS \\
\cline { 4 - 4 } & & & MDL $\left(\mathrm{mg} \mathrm{L}^{-1}\right)$ \\
\hline 1 & Nap & Naphthalene & 0.000098 \\
\hline 2 & Acy & Acenaphtylene & 0.000056 \\
\hline 3 & Ace & Acenaphtene & 0.000025 \\
\hline 4 & Fle & Fluorene & 0.000037 \\
\hline 5 & Phe & Phenanthrene & 0.000039 \\
\hline 6 & Ant & Anthracene & 0.000025 \\
\hline 7 & Fla & Fluoranthene & 0.000024 \\
\hline 8 & Pyr & Pyrene & 0.000012 \\
\hline 9 & BaA & Benzo(a)anthracene & 0.000049 \\
\hline 10 & Chr & Chrysene & 0.000215 \\
\hline 11 & BbF & Benzo(b)fluoranthene & 0.000124 \\
\hline 12 & BkF & Benzo(k)fluoranthene & 0.000072 \\
\hline 13 & BaP & Benzo(a)pyrene & 0.000074 \\
\hline 14 & BeP & Indeno(1,2,3-cd)pyrene & 0.000193 \\
\hline 15 & DaA & Dibenzo(a,h)anthracene & 0.00039 \\
\hline 16 & BgP & Benzo(g,h,i)perylene & 0.000164 \\
\hline & & & \\
\hline
\end{tabular}

Table 2: Method Detection Limits (MDL) of PAHs for GC-MS

The standard curves were obtained 10, 50, 100, 500 and $1000 \mu \mathrm{g} \mathrm{l}^{-1}$ $\mathrm{PAH}$ standards and the response curves for $16 \mathrm{PAHs}$ were linear with correlation coefficients around 0.99 . The range of $r$ values lies between 0.997-1.000. The method detection limits ranged from $0.000012-0.000390 \mathrm{mg} / \mathrm{L}$ as can be seen from Table 2, The method detection limits were determined based on the concentration (or amount) of an analyte which gave a signal three times the background noise.

\section{Total Organic Carbon (TOC) Analysis}

Total organic carbon (TOC) of sediments was analyzed using an element analyzer (LECO, CHNS-932 Elemental Analyzer). The sediments were first acidified with $10 \%(\mathrm{v} / \mathrm{v}) \mathrm{HCl}$ overnight to remove carbonate, then dried at 60 and analyzed for TOC $[9,10]$.

\section{Results}

\section{Effect of total organic carbon on total PAHs in sediment}

Figure 2 shows very low correlation between total PAH concentrations and TOC content $(\mathrm{r} 2=0.0732)$ Many studies indicated that similar correlation shows that TOC content is an important controlling factor for the sorption of PAHs on sediments [9]. Usually in lakes different hydraulic conditions lead to different sediment properties, e.g. TOC content. In our case it ranged from 0.280 to $4.01 \%$, with an average of $1.96 \pm 0.710 \%$.

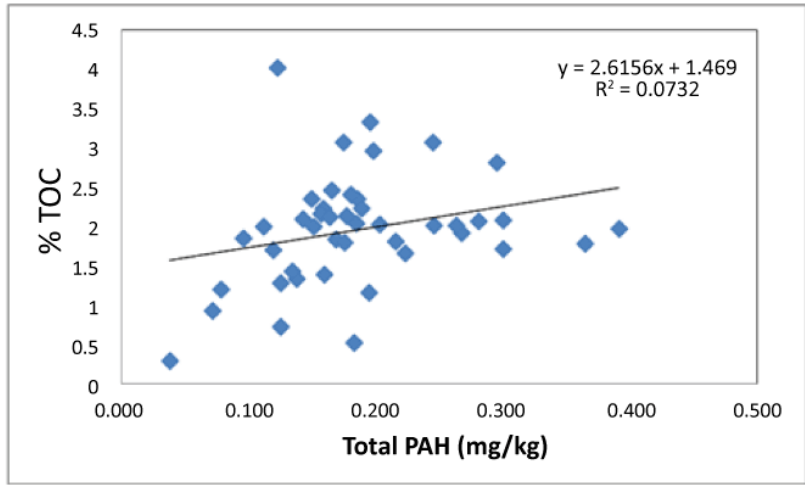

Figure 2: PAH Cross Plots for the \% TOC vs total PAH

PAH concentrations were normalized with respect to TOC contents in order to reduce the effect of sediment property on the concentrations. Total PAH/TOC concentrations in 44 İkizcetepeler sediment samples were calculated separately and were given in Figure 3. The normalized PAH concentrations ranged from 5.20 to 35.2 $\mathrm{mg} / \mathrm{kg}$-TOC with an average of $10.6 \pm 5.55 \mathrm{mg} / \mathrm{kg}$-TOC. As can be seen from the Figure 3 total PAH/TOC concentrations are especially higher in sediment samples; 33 (west of the dam lake), 1 (north of the dam lake), 9 (north of the dam lake), 42 (west of the dam lake), 32 (west of the dam lake) and 23 (east of the dam lake).

\section{PAHs in sediments}

The average concentrations of 16 measured PAHs in İkizcetepeler Dam Lake sediment samples were given in Table 3. As can be seen from the table, high concentration was observed for Nap and BeP and it was $0.020 \mathrm{mg} / \mathrm{kg}$. The $\mathrm{BaA}$ and $\mathrm{DaA}$ both had the lowest concentration which was $0.005 \mathrm{mg} / \mathrm{kg}$. General concentration profile was as following;

$\mathrm{Nap}=\mathrm{BeP}>\mathrm{Phe}=\mathrm{Ant}>\mathrm{BgP}=\mathrm{Att}>\mathrm{IcP}>\mathrm{Fla}>\mathrm{Chr}=\mathrm{BbF}>\mathrm{BkF}=\mathrm{BaP}=\mathrm{Fle}=$ Pyr $>$ Ace $>$ Acy $>\mathrm{DaA}=\mathrm{BaA}>$ Cycpyr.

The average sum PAH concentrations were $0.19 \pm 0.07 \mathrm{mg} / \mathrm{kg}$ which is higher than expected. 
Citation: Topal T, Tecer LH, Tuncel SG (2014) Chemical Characteristics and Source Apportionment of Polycyclic Aromatic Hydrocarbons (PAHs) in Surface Sediments of the Ikizcetepeler Dam Lake of Northwestern Turkey. J Environ Anal Chem 1: 117.

Page 4 of 7

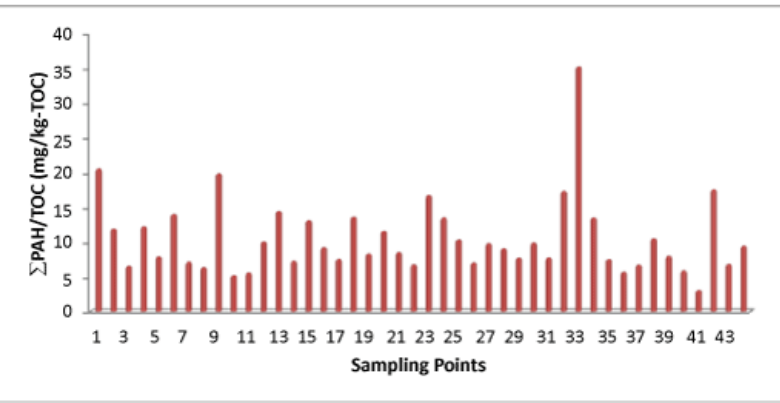

Figure 3: $\quad \mathrm{PAH} / \mathrm{TOC}$ Concentrations $(\mathrm{mg} / \mathrm{kg}-\mathrm{TOC})$ in İkizcetepeler Dam Lake Sediment Samples $(\mathrm{n}=44)$

\begin{tabular}{|l|l|l|l|}
\hline \multirow{2}{*}{ No } & PAHs & Average & Average Standardized \\
\cline { 3 - 4 } & & PAH Conc. \pm Stdev & PAH Conc. \pm Stdev \\
\cline { 3 - 4 } & & (mg/kg) & (mg/kg-TOC) \\
\hline 1 & Nap & $0.020 \pm 0.011$ & $1.13 \pm 0.779$ \\
\hline 2 & Acy & $0.0060 \pm 0.0010$ & $0.329 \pm 0.0771$ \\
\hline 3 & Ace & $0.0070 \pm 0.0020$ & $0.396 \pm 0.224$ \\
\hline 4 & Fle & $0.0080 \pm 0.0030$ & $0.555 \pm 0.723$ \\
\hline 5 & Phe & $0.018 \pm 0.011$ & $1.10 \pm 0.975$ \\
\hline 6 & Ant & $0.018 \pm 0.011$ & $1.05 \pm 0.731$ \\
\hline 7 & Fla & $0.010 \pm 0.003$ & $0.560 \pm 0.270$ \\
\hline 8 & Pyr & $0.0080 \pm 0.0030$ & $0.419 \pm 0.166$ \\
\hline 9 & BaA & $0.0050 \pm 0.0020$ & $0.286 \pm 0.160$ \\
\hline 10 & Chr & $0.0090 \pm 0.0040$ & $0.504 \pm 0.286$ \\
\hline 11 & BbF & $0.0090 \pm 0.0030$ & $0.480 \pm 0.266$ \\
\hline 12 & BkF & $0.0080 \pm 0.0030$ & $0.470 \pm 0.270$ \\
\hline 13 & BaP & $0.0080 \pm 0.0030$ & $0.470 \pm 0.217$ \\
\hline 14 & BeP & $0.020 \pm 0.023$ & $1.03 \pm 1.22$ \\
\hline 15 & DaA & $0.0050 \pm 0.0050$ & $0.292 \pm 0.250$ \\
\hline 16 & BgP & $0.017 \pm 0.007$ & $0.908 \pm 0.518$ \\
\hline & $\sum \mathrm{PAH}$ & $0.19 \pm 0.07$ & $10.6 \pm 5.55$ \\
\hline & & & \\
\hline
\end{tabular}

Table 3:The Average and Average Standardized PAH Concentrations $(\mathrm{mg} / \mathrm{kg})$ in İkizcetepeler Dam Lake Sediments

\section{Sediment quality determinations for İkizcetepeler sediments}

In order to determine the quality of the sediments collected the recommended sediment quality values for 16 PAHs was used. Individual concentrations given in Table 3 were used to generate Table 4.
According to the consensus-based sediment quality guidelines (CBSQGs) three classes (explaining toxicity level) exist; TEC, MEC and PEC. The TEC (threshold effect concentration); lower concentration at which toxicity to benthic-dwelling organisms are predicted to be unlikely. The PEC (probable effect concentration); upper concentration at which toxicity to benthic-dwelling organisms are predicted to be probable. The MEC (midpoint effect concentration); is a concentration midway between the TEC and PEC concentrations (TEC + PEC / 2=MEC). There are four levels which are; Level 1 ( $\leq$ TEC), Level 2 (TEC<Level $2 \leq \mathrm{MEC}$ ) and Level 3 $(\mathrm{MEC}<$ Level $3 \leq \mathrm{PEC})$ and Level 4 ( $>$ PEC).

\begin{tabular}{|c|c|c|c|c|c|}
\hline \multirow[t]{2}{*}{$\begin{array}{l}\text { PAH } \\
(\mathrm{mg} / \mathrm{kg})\end{array}$} & \multirow[t]{2}{*}{ TEC-MEC-PEC } & $\begin{array}{l}\text { Level } \\
1\end{array}$ & Level 2 & Level 3 & $\begin{array}{l}\text { Level } \\
4\end{array}$ \\
\hline & & $\leq T E C$ & $\begin{array}{l}>\text { TEC- } \\
\leq \text { MEC }\end{array}$ & $\begin{array}{l}>\text { MEC- } \\
\leq \text { PEC }\end{array}$ & $>$ PEC \\
\hline Nap & $\begin{array}{l}0.1760-0.3690-0.561 \\
0\end{array}$ & & & & 1.13 \\
\hline Acy & $\begin{array}{l}0.0059-0.0670-0.128 \\
0\end{array}$ & & & & 0.329 \\
\hline Ace & $\begin{array}{l}0.0067-0.0480-0.089 \\
0\end{array}$ & & & & 0.396 \\
\hline Fle & $\begin{array}{l}0.0774-0.3070-0.536 \\
0\end{array}$ & & & & 0.555 \\
\hline Phe & $0.2040-0.6870-1.170$ & & & 1.1 & \\
\hline Ant & $\begin{array}{l}0.0572-0.4510-0.845 \\
0\end{array}$ & & & & 1.05 \\
\hline Fla & $0.4230-1.327-2.230$ & & 0.56 & & \\
\hline Pyr & $0.1950-0.8580-1.520$ & & 0.419 & & \\
\hline $\mathrm{BaA}$ & $0.1080-0.5790-1.050$ & & 0.286 & & \\
\hline Chr & $0.1660-0.7280-1.290$ & & 0.504 & & \\
\hline $\mathrm{BbF}$ & $0.2400-6.820-13.40$ & & 0.48 & & \\
\hline BkF & $0.2400-6.820-13.40$ & & 0.47 & & \\
\hline $\mathrm{BaP}$ & $0.1500-0.8000-1.450$ & & 0.47 & & \\
\hline $\mathrm{BeP}$ & $0.1500-0.8000-1.450$ & & & 1.03 & \\
\hline $\mathrm{BgP}$ & $0.1700-1.685-3.200$ & & 0.908 & & \\
\hline
\end{tabular}

Table 4: Sediment Quality Guidelines (SQGs) for PAHs

To compare the study site concentrations with the CBSQs concentrations on a common basis, study site concentrations should be divided by the study site $\%$ total organic carbon (TOC) concentrations to yield a dry wt. normalized value. When no site TOC information is available \% TOC is assumed as 1 [11]. In this study TOC information was available therefore study site $\mathrm{PAH}$ concentrations were divided by \% TOC values. According to the Table; $\mathrm{BgP}$ is in Level 1, Fla, Pyr, BaA, Chr, BbF, BkF, BaP, IcP are in Level 2, Phe, BeP are in Level 3, and Nap, Ace, Acy, Fle, Ant and DaA are in Level 4. 
Citation: Topal T, Tecer LH, Tuncel SG (2014) Chemical Characteristics and Source Apportionment of Polycyclic Aromatic Hydrocarbons (PAHs) in Surface Sediments of the Ikizcetepeler Dam Lake of Northwestern Turkey. J Environ Anal Chem 1: 117.

Page 5 of 7

\section{Statistical analyses}

To interpret the obtained data, some calculations and statistical tests were applied. First diagnostic ratios were calculated to classify the $\mathrm{PAHs}$ in two broad source categories. To obtain detailed source categories, Factor analysis was applied.

Factor analysis (FA) was performed on normalized PAH concentrations using SPSS 17.0 package program. Factor analysis is a multivariate analysis which groups the variables with the same variance in the same factor (principal components). The factors with eigenvalues over 1 were extracted according to Kaiser-Meyer-Olkin (KMO) and Bartlett's test of sphericity and were rotated using the Varimax method. Extracted factors are assigned as source depending on the variables which make up the factor. The assumption is, the variables with the same variance are assumed to be originating from the same source. Factor analyses provide only qualitative information about the source type. If quantitative information is required than another approaches like 'receptor modeling' could be used. Diagnostic ratio analysis was achieved simply by taking the ratio of the selected analytes and explained below.

\section{Diagnostic ratios of PAHs}

In order to distinguish petrogenic sources and pyrogenic sources, molecular fingerprints of PAH isomers within the same molecular weight are used. As a result of this kind of source tracer's studies, different $\mathrm{PAH}$ ratios were found. For example a 178 mass PAH ratio which is anthracene/(anthracene + phenanthrene). Assigned threshold values to each $\mathrm{PAH}$ ratios also helps in determination of source type. However this method has some disadvantages. Although it is a helpful tool for qualitative determinations it is not quantitative. Another limitation is the degradation of PAHs in environment, with different rates which in turn affects the ratio. Therefore diagnostic ratio by itself is not enough to comment about the sources, it must be supported by another statistical analysis like FA [12].

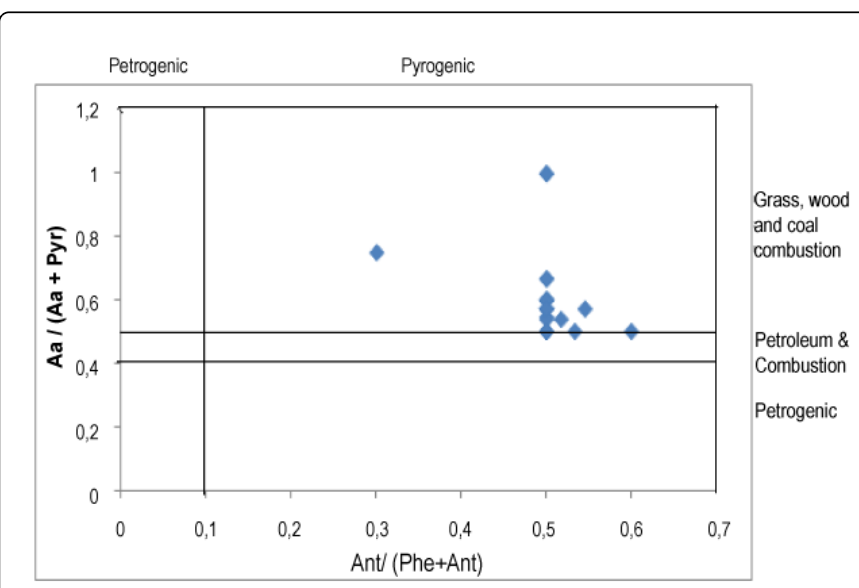

Figure 4: PAH Cross Plots for the Ratios of Ant/(Ant + Phe) vs. Fla/ $(\mathrm{Fla}+\mathrm{Pyr})$

According to the Figure 4, PAHs in sediments with the ratio of Anthracene to Anthracene plus Phenanthrene; Ant/(Ant + Phe $)>0.1$ were typical of combustion sources (pyrogenic source). In addition, PAHs in sediments with the ratio of Fluoranthene to Fluoranthene plus Pyrene; Fla $/(\mathrm{Fla}+\mathrm{Pyr})>0.5$ indicates $\mathrm{PAHs}$ are mainly from combustion of grass, wood and coal and $0.4<\mathrm{Fla} /(\mathrm{Fla}+\mathrm{Pyr})<0.5$ from combustion of petroleum [3].

As depicted in Figure 4, most ratios generated in this study pointed to a source from grass/wood/coal combustion. The second major source might be petroleum combustion (automobile emission). With the data at hand, it can be concluded that pyrogenic origins might be the dominant PAH source in İkizcetepeler Dam Lake.

\section{Factor analysis (FA) for İkizcetepeler samples}

Factor Analysis is a statistical tool to groups the parameters with the same variance in the same factor. The similarities in variations considered as a common source for the parameters grouped in the same factor [13-15]. By considering factor loadings as the degree of correlation of ech parameter with the factor one can assign a source for each factor. FA solution for the PAH concentrations from the İkizcetepeler sediments were presented in Table 5.

\begin{tabular}{|c|c|c|c|c|c|}
\hline & & Factor & Analysis & Results & \\
\hline No & PAH & 1 & 2 & 3 & $\begin{array}{l}\text { Communa } \\
\text { lities }\end{array}$ \\
\hline 1 & Nap & 0.686 & 0.162 & 0.471 & 0.718 \\
\hline 2 & Ace & 0.778 & 0.139 & 0.199 & 0.663 \\
\hline 3 & Fle & 0.046 & -0.068 & 0.876 & 0.774 \\
\hline 4 & Phe & 0.660 & 0.307 & 0.626 & 0.922 \\
\hline 5 & Ant & 0.303 & 0.357 & 0.791 & 0.845 \\
\hline 6 & Fla & 0.615 & 0.586 & 0.454 & 0.928 \\
\hline 7 & Pyr & 0.183 & 0.817 & 0.214 & 0.747 \\
\hline 8 & Cyсpyr & 0.905 & 0.161 & 0.075 & 0.851 \\
\hline 9 & Chr & 0.704 & 0.599 & 0.114 & 0.868 \\
\hline 10 & $\mathrm{BbF}$ & 0.731 & 0.625 & 0.162 & 0.951 \\
\hline 11 & $\mathrm{BkF}$ & 0.719 & 0.623 & 0.160 & 0.931 \\
\hline 12 & $\mathrm{BaP}$ & 0.597 & 0.661 & 0.139 & 0.812 \\
\hline 13 & IcP & 0.514 & 0.765 & 0.148 & 0.872 \\
\hline 14 & $\mathrm{DaA}$ & 0.057 & 0.704 & -0.020 & 0.499 \\
\hline 15 & $\mathrm{BgP}$ & 0.687 & 0.536 & 0.170 & 0.788 \\
\hline 16 & Att & 0.762 & 0.242 & 0.173 & 0.670 \\
\hline \multicolumn{2}{|c|}{ Estimated Source } & Mixed & Pyrogenic & Petrogenic & \\
\hline \multicolumn{2}{|c|}{ Variance (\%) } & 37.9 & 26.9 & 15.4 & \\
\hline \multicolumn{2}{|c|}{ Total Variance } & 37.9 & 64.8 & 80.2 & \\
\hline \multicolumn{5}{|c|}{ Rotation Method: Varimax with Kaiser Normalization, } & \\
\hline \multicolumn{5}{|c|}{ Bold Loadings $>0.70$} & \\
\hline
\end{tabular}

Table 5: Factor Analysis (FA) Results

According to FA results in Table 5, there were three factors accounting for 80.2 of the total variance in the data. Among three factors; Factor 1 is responsible for 37.9 of the total variance and heavily 
Citation: Topal T, Tecer LH, Tuncel SG (2014) Chemical Characteristics and Source Apportionment of Polycyclic Aromatic Hydrocarbons (PAHs) in Surface Sediments of the Ikizcetepeler Dam Lake of Northwestern Turkey. J Environ Anal Chem 1: 117.

Page 6 of 7

weighted in Ace, Cycpyr, Chr, BbF, BkF, Att (mostly HPAHs; 4-6 rings). Factor 2 contributing $26.9 \%$ of total variance, and it is highly weighted by Pyr, IcP and DaA (HPAHs; 4-6 rings). Factor 3 explains 15.4 of total variance and it is highly dominated by LPAHs (2-3 rings); Fle and Ant.

Pyrogenic sources, such as the combustion-derived particles present in urban atmospheric dust, were depleted in LPAHs and enriched in HPAHs. Petrogenic sources, such as fuel oil or light refined petroleum products, were dominated by LPAH [3].

Therefore, Factor 1, corresponding to the first group, represent a mixed source (both pyrogenic and petrogenic); Factor 2, corresponding to the second group, represents also pyrogenic source PAHs (coal combustion; 4 rings PAH and traffic related pollution; 5-6 rings PAHs). Factor 3, corresponding third group, represents petrogenic source (2-3 rings PAHs).

\section{Pollution maps}

Geographical information systems (GIS) software, Mapinfo 7.5 was used for the construction of pollution maps of PAHs in İkizcetepeler Dam Lake. The PAH distributions in Dam Lake are given in Figure 5; the points were selected all over the dam lake considering the high $\mathrm{PAH}$ concentrations.

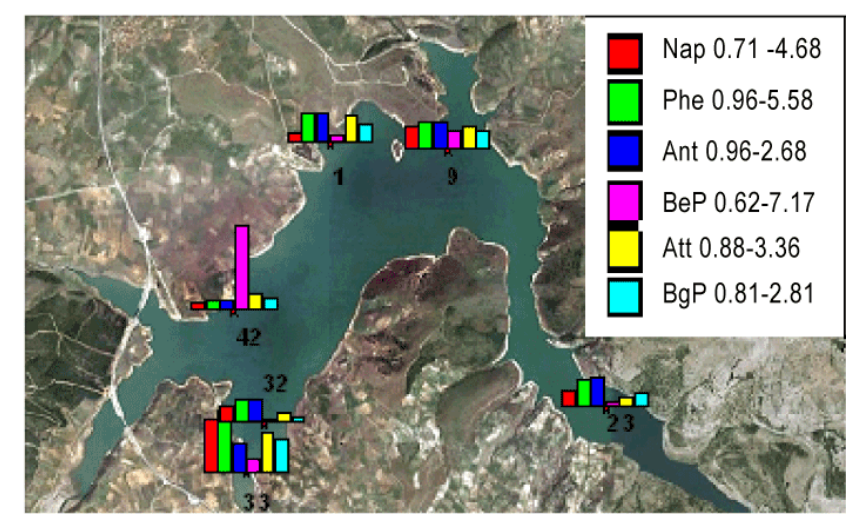

Figure 5: Map of PAH Distributions $(\mathrm{mg} / \mathrm{kg})$ in İkizcetepeler Dam Lake

In order to draw pollution profile the points at which higher concentrations of selected PAHs were observed, were chosen. These points were $33,1,9,42,32$ and 23 . The selected PAH concentrations at these points were in the following order; $33>1>9>42>32>23$. The PAHs were not including all of 16 PAHs but the mostly observed 6 PAHs which were Nap, BeP, Phe, Ant, BgP and Att. Among the points 42,32 and 33 were in the west of the dam lake and near to the road. Points 1 and 9 were in the north of the dam lake and 23 were in the east of the lake. The mostly polluted site was 33, west of the dam lake. Therefore it can be concluded that traffic is the important PAH source in this area. The order of the average standardized $\mathrm{PAH}$ concentrations were as the following; Nap $>$ Phe $>$ Ant $>$ BeP $>$ Att $>$ BgP.

\section{Conclusion}

Chemical composition of PAH compounds in İkizcetepeler Dam lake sediment samples were determined with high recoveries by using
HP 6890 series GC coupled to mass detector. Detection limits and accuracy of the analyses were in accepted range.

The concentrations of 16 PAHs in İkizcetepeler Dam Lake sediment samples were quite low. The highest concentrations were observed for Nap and Bep and they were $0.020 \mathrm{mg} / \mathrm{kg}$. High concentrations were also observed for Phe, Ant, BgP and Att. The Cycypyr had the lowest concentration which was $0.004 \mathrm{mg} / \mathrm{kg}$. The $\mathrm{DaA}$ and $\mathrm{BaA}$ have also low concentrations. The average sum PAH concentration was $0.19 \pm$ $0.07 \mathrm{mg} / \mathrm{kg}$ in İkizcetepeler Dam Lake sediments.

According to FA results; there were 3 factors account for $80.2 \%$ of the variability in the data. Factor 1 (explains $37.9 \%$ of the total variance), represents a mixed source (petrogenic; coal combustion; 4 rings $\mathrm{PAH}$ and traffic related pollution; 5-6 rings PAHs), Factor 2 (explains 26.9 of the total variance) represents also pyrogenic source PAHs and Factor 3 (explains 15.4 of the total variance), represents petrogenic source.

To sum up the FA and diagnostic analyses results supported each other and indicated that pyrogenic (the most common) and petrogenic sources are the important sources of PAHs in Dam Lake.

\section{References}

1. Traven L (2013) Sources, trends and ecotoxicological risks of PAH pollution in surface sediments from the northern Adriatic Sea (Croatia). Mar Pollut Bull 77: 445-450.

2. Ruiz-Ferna'ndez AC, Sprovieri M, Piazza R, Frignani M, Sanchez-Cabeza JA, et al. (2012) 210Pb-derived history of PAH and PCB accumulation in sediments of a tropical inner lagoon (Las Matas, Gulf of Mexico) near a major oil refinery. Geochim Cosmochim Ac 82: 136-153.

3. Liu Y, Chen L, Jianfu Z, Qinghui H, Zhiliang Z, et al. (2008) Distribution and sources of polycyclic aromatic hydrocarbons in surface sediments of rivers and an estuary in Shanghai, China. Environ Pollut 154: 298-305

4. Deng W, Li XG, Li SY, Ma YY, Zhang da H (2013) Source apportionment of polycyclic aromatic hydrocarbons in surface sediment.

5. Alper A, Çelebi E, Çam H, Karaytuğ S (2007) Cladocera and Copepoda (Crustacea) fauna of İkizcetepeler dam lake (Balıkesir, Turkey). Turk J of Fish Aquat Sc 7: 71-73.

6. Şahin İ, Tünay Z, Nakiboğlu N (2004) Determination of arsenic in İkizcetepeler dam lake's water by cathodic stripping voltammetry. Adnan Menderes University, Aydın, Turkey.

7. Torcu-Koç H, Türker-Çakır D, Ulunehir G (2008) An investigation in fish fauna İkizcetepeler dam lake (Balıkesir), Turkey. J Appl Biol Sci 2: 63-67.

8. Tuncel SG, Topal T (2011) Multifactorial optimization approach for determination of polycyclic aromatic hydrocarbons in sea sediments of Turkish Mediterranean coast. AJAC 2: 783-794.

9. Zhang J, Cai L, Yuan D, Chen M (2004) Distribution and sources of polynuclear aromatic hydrocarbons in Mangrove surficial sediments of Deep Bay, China. Mar Pollut Bull 49: 479-486.

10. Hedges, JI, Stren, JH (1984) Carbon and nitrogen determinations of carbonate-containing solids. ASLO 29: 657-663.

11. http://dnr.wi.gov/topic/brownfields/documents/cbsqg_interim_final.pdf.

12. Sofowote UM, Allan LM, McCarry BE (2010) Evaluation of PAH diagnostic ratios as source apportionment tools for air particulates collected in an urban-industrial environment. J Environ Monit 12: 417424.

13. Bilkis A, Hopke P, Zhao W (2005) Source Identification of Fine Particles in Washington, DC, by Expanded Factor Analysis.Modeling. Environmental Science And Technology 39: 1129-1137.

14. Boitsov S, Petrova V, Jensen HKB, Kursheva A, Litvinenko I et al. (2013) Sources of polycyclic aromatic hydrocarbons in marine sediments from 
Citation: Topal T, Tecer LH, Tuncel SG (2014) Chemical Characteristics and Source Apportionment of Polycyclic Aromatic Hydrocarbons (PAHs) in Surface Sediments of the Ikizcetepeler Dam Lake of Northwestern Turkey. J Environ Anal Chem 1: 117. doi:10.4172/2380-23911000117

Page 7 of 7

southern and northern areas of the Norwegian continental shelf. Mar Environ Res 87-88: 73-84.
15. Boehm PD (2006) Polycyclic Aromatic Hydrocarbons (PAHs). In: Morrison R, Murphy B (eds) Environmental Forensics, Contaminant Specific Guide. Academic Press. 